\title{
CORROSION PROCESSES ON MAGNESIUM IN ELECTROLYTES BASED ON THE DIMETHYLFORMAMIDE
}

\author{
G.S. Rahymbay, A.M. Argymbayeva, B.D. Burkitbayeva, A.P. Kurbatov
}

Corrosion processes on magnesium in non-aqueous dimethylformamide solutions are research. The formation of the surface passivating film, which has a different conductivity due to recovery of the solvent molecules.

\section{УДК 556.114}

\section{ЕРТІС ГИДРОЭКОЛОГИЯЛЫҚ АЙМАҒЫНЫҢ СУЫНЫН САПАСЫ}

\author{
С.М. Романова, Ж.Д. Достай, Р.Г. Рысқалиева \\ Әл-Фараби атындағы Қазақ ұлттық университеті \\ ҚР ҒБМ жанындағы ЖШС «География институты»
}

\begin{abstract}
Мақ̆алада Ертіс гидроэкологиялық ауданының негізгі өзендерінің суының сапасын багалау мақссатында жүргізілген зерттеулер нәтижелері баяндалван.
\end{abstract}

Шығыс Қазақстан облысының (ШҚО) Ертіс гидроэкологиялық ауданының басты өзені үш мемлекетпен - Қытай, Ресей және Қазақстанмен шекаралас ағатын Ертіс өзені болып табылады. Оның ірі ағыстары Бұқтырма,Үлбі, Оба, Күршім өзендері. Осы аймақтың ірі көлдері - Жайсаң, Марқакөл, Алакөл және Сасықкөл. Одан басқа оңтүстік - Батыс Алтайда жалпы ауданы 99 кв. км 350 мұздықтар бар. Сонымен қатар осы облысқа Алтай, Жарма-Сауыр, Шыңғыс-Тарбағатай үш кен аймағы да кіреді.

Ертіс өзенінің суының химиялық құрамының қалыптасуы құрамына Қара Ертіс өзені, Жайсаң көлі, Бұқтырма су қоймасы және көптеген ағыстар кіретін Зайсан-Бұқтырма бассейінінің территориясында жүзеге асады.

Республикадағы жалпы су құрамы бойынша талдау жасағанда ең ластанған суларға өзендер жатады. Әсіресе өндіріс орындары көп шоғырланған жерлерде жауын-шашынның әсерінен (жылына 600-700 мм) олардағы ластаушы заттар өзендер мен жер асты суларының құрамына енеді. Жоғарғы Ертіс өзенінің суы ағыс бойынша әрі қарай осы аймақтың жергілікті тұрғындарын сумен қамтамасыз етуге жұмсалады. Одан кейін осы өзеннің суы Қазақстан территориясынан шығып, Ресей Федерациясына кетеді. Осыған байланысты барлық су ресурстарының құрамын зерттеу қажеттігі туындайды.

Үлбі, Тихая және Брекса өзендеріне АҚ «Казцинк» кешенінің Лениногор тау-кен байыту комбинатының; Бұқтырма өзеніне Зыряновск тау-кен байыту комбинатының (АҚ «Казцинк» Малеев кеніші); Красноярка және Глубочанка өзендеріне - «Казахмыс» корпорациясының Белоусов тау-кен байыту комбинатының қалдықтары келіп түседі.

Облыстың су нысандарына барлығы 100 мыңға дейін әртүрлі заттар: 125,5 тонна мырыш, 5,5 тонна мыс, 0,759 тонна қорғасын тасталынады, бұл өз кезегінде Ертіс бассейінінің акваториясының экожүйесінің ластануына әкеледі /1/.

Қара Ертіс - ұзындығы 735 км тау өзені. Оған өте аз және аз минерализация (орташа жылдық мәні 120 мг/л) тән, оның өзгерісі су ағынының өзгеруіне байланысты шамамен 40 \% құрайды. Судың иондық құрамында $\mathrm{HCO}_{3}^{-}, \mathrm{Ca}^{2+}$, сирек $\mathrm{Na}^{+}$иондары, $\mathrm{Mg}^{2+}, \mathrm{SO}_{4}^{2-}, \mathrm{Cl}^{-}$иондары кездеседі.

Ертіске ағатын ірі оң жағалау ағыстарының біразы (Кальджир, Күршім, Бұқтырма, Үлбі, Оба) жылдың көп мезгілінде аз минерализацияланумен сипатталады. Мысалы, ең ірі оң жағалаулы ағыс Бұқтырма өзені үшін минералданудың орташа мәні 119 мг/л (Заводино селосы) құрайды, оның жылдық циклдегі өзгерісі 29\%-дан аспайды.

Сол жағалауға құятын ағыстардың, әдетте суы аз болады да, оң жағалауға қарағанда минерализациялануы жоғары иондар қатынасы, кермектігі, органикалық заттардың құрамы бойынша ерекшеленеді. Су қоймаларын (Бөкен, Тентек, Кұлұджұн, Қайыңды, Тайынты) қамтамасыз ететін жоғарғы сол жағалау ағыстарына жылдың көп мезгілінде орташа (140 - 230 мг/л), ал Көкпекті өзеніне жоғары минерализациялану (600 мг/л) тән.

Ертіс өзенінің гидрохимиялық режимі өзен ағысы бойынша біршама өзгеріске ұшырайды. Ағыстарды реттеуге байланысты жыл бойы минералданудың өзгеруі төмендейді (Боран селосының 
маңында 40\%-дан Өскемен маңында 11\%-ға дейін), рН мәні мен органикалық заттардың мәні тұрақты болады. Одан төмен қарай (Старая Шульба селосы) химиялық компоненттердің жаңа өзгерістері Үлбі өзенінің ағыстарына байланысты өзгереді. Павл қаласының маңында су ағысы мен химиялық құрамының қалыптасуы аяқталған. Минерализацияланудың өзгеруі 14\%-ға дейін артады, ал Ертіс селосында 30\% құрайды. Мұнда иондар мен рН мәндері және органикалық заттар арасында кейбір өзгерістер байқалады.

Минерализацияның жалпы тенденциясының артуын қарастырғанда өзен ағыстары бойынша оның кейбір бөліктерінде мәндерінің біршама артқанын немесе төмендегенін байқауға болады. Жаз мезгілдерінде Қара Ертіс, Жайсаң өзені-Бұқтырма су қоймасында минерализациялану артады, бірақ Бұқтырма өзенінің әсерінен (Серебрянск қаласының маңы) оның төмендегені байқалады. Сәуір айында Қара Ертіс өзенінің минерализациясы Жайсаң өзеніне қарағанда жоғары болады.

Төмен қарай Өскемен қаласында өзен ағысының бойында орналасқан жерлерде минерализацияланудың орташа жылдық мәні артады. Хлор коэффициенттерінің мәндерін талдау негізінде минерализацияланудың артуы жеке иондардың жиналуына байланысты болмайтындығы анықталған. Одан басқа өзен ағысы бойынша су типінің өзгерісі О.А. Алекин жіктеуі бойынша жүзеге асады: $\mathrm{C}_{I}^{\mathrm{Ca}} \rightarrow \mathrm{C}_{I I}^{\mathrm{Ca}}$.

Шығыс Қазақстан облысындағы Ертіс өзенінің бассейіні өте ластанған су көздеріне жатады. Оның ішінде көбінесе Красноярка, Брекса, Тихая, Глубочанка және Емел өзендерінің суы өте ластанған. Шығыс Қазақстан облысының суларының ластануының кешенді индексінің өзгеру динамикасы (СЛКИ) көп жылдық циклде (2001 - 2008 жылдар аралығында) 1 суретте көрсетілген. Өзен суларының ластануының кешенді индексінің мәні 7,0- 38,0 аралығында, бұл өз кезегінде «ластанудың жоғары деңгейі» дәрежесінде деп пайымдауға мүмкіндік береді (СЛКИ 10,0-нан үлкен) $/ 2 /$.

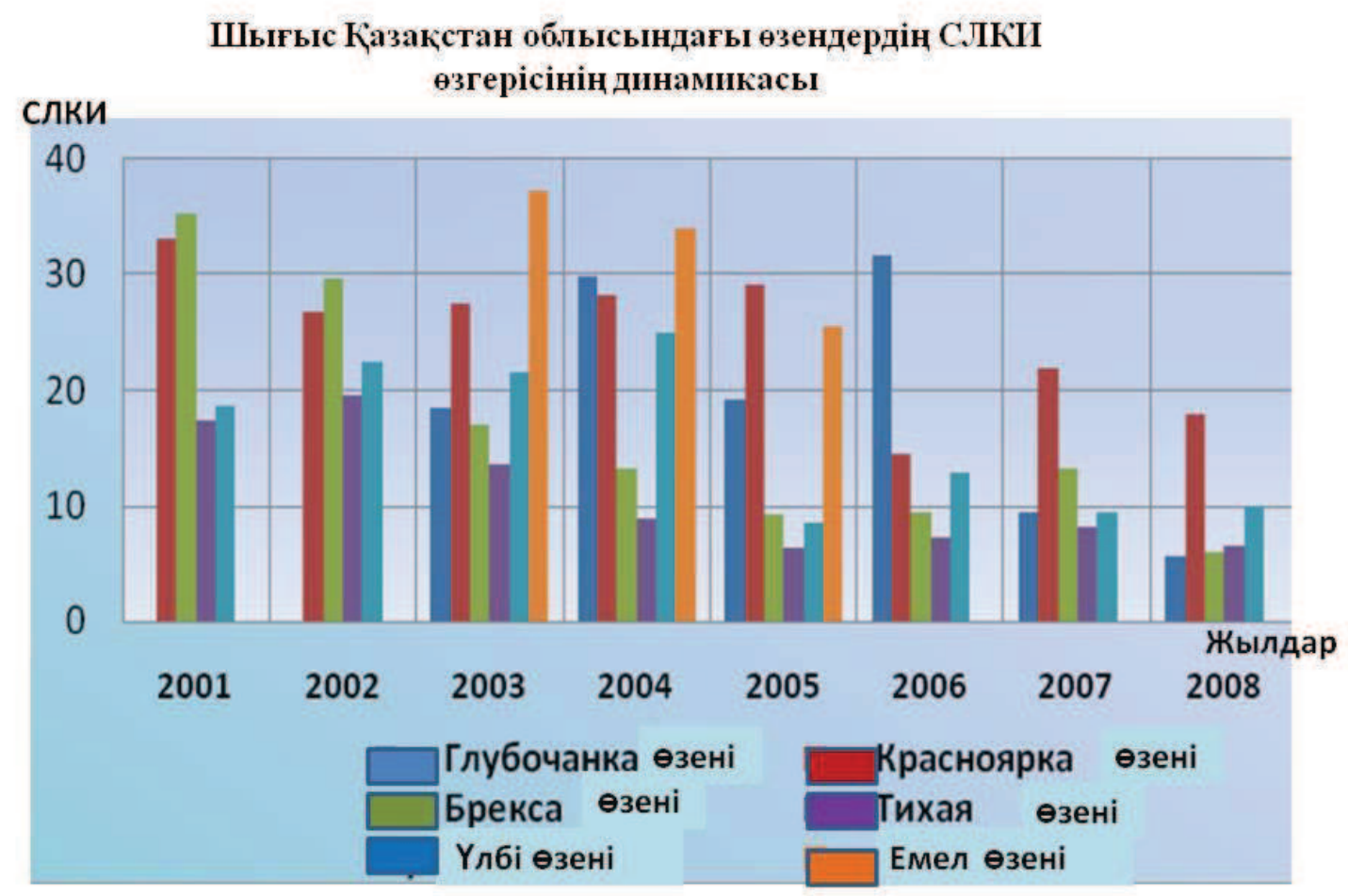

1-сурет. Шығыс Қазақстан облысының өзендері суларының өзгеру динамикасы

Бұл аймақтың өзен суларында көбінесе нитритті азот, мыс, мырыш және мұнай өнімдері бойынша ластану байқалады. Тихая өзенінде нитритті азот бойынша (1,8 ШРК), мыс (12 ШРК), мырыш (18,5 ШРК) және мұнай өнімдері (2,8 ШРК) шектеулі рұқсат етілген концентрациядан көп болатындығы байқалған. Брекса өзенінде нитритті азот бойынша шектеулі рұқсат етілген концентрациядан асып кетуі (1,8 ШРК), мыс (12 ШРК), мырыш (25,5 ШРК), мұнай өнімдері (2,8 
ШРК) анықталған. Глубочанка өзенінде нитритті азот бойынша (2,9 ШРК), мыс (11 ШРК), мырыш (10,3 ШРК) және мұнай өнімдері (2,6 ШРК). Үлбі өзенінің ластану жағдайы СЛИ - 3,17 және 4 класқа жатады - «ластанған». ШРК асуы мыс және мырыш (7 ШРК), мұнай өнімдері бойынша (3,0 ШРК) байқалады /3-4/.

Жер бетіндегі сулардың ластануы полиметалл кендерін байыту және өндіру аймақтарында байқалады. Егер ҚР басқа су бассейндерінде су сапасының жақсаруы байқалса, Шығыс Қазақстан облысының өзен суларында ластану дәрежесінің тұрақты болғандығы байқалған. Әсіресе Брекса, Тихая (Риддер қаласы), Үлбі (Тишинск кеніші) өзендерінің суының сапасы соңғы кездері төмендеген.

2009 жылдың 6-12 қыркүйегі аралығында Шығыс Қазақстан облысының өзендері мен су қоймаларынан үлгі алынып, жүргізілген зерттеулер нәтижесі бойынша біршама қорытынды жасауға болады. Мұнда су құрамындағы басты иондар, биогенді заттар мен органикалық заттар, фтор, марганц гидрохимия саласындағы жалпылама әдістермен анықталды. Осы мәліметтер бойынша профессор М.Ж. Бөрлібаев ұсынған әдістемемен судың ластану индексі есептелді /2/.

Зерттеу нәтижелері бойынша 15 өзеннің ішінде тек 2 өзен ғана (Жаман Қоба және Қара Қоба) минерализациясы өте аз (100 мг/л-ге дейін), қалғандары - аз (200 мг/л-ге дейін) немесе орташа (200500 мг/л), ал Аягөз өзені жоғары (843,3 мг/л) мәнге ие. Көп жағдайда иондық құрамында гидрокарбонаттар мен кальций, сирек натрий иондары болатындығы анықталған, су типі екінші және үшінші типті, О.А. Алекин бойынша судың индексі $\mathrm{C}_{\Pi}^{\mathrm{ca}}, \mathrm{C}_{1}^{\mathrm{ca}} \mathrm{C}_{1}^{\mathrm{Na}} \mathrm{C}_{1}^{\mathrm{ca}}{ }_{1}, \mathrm{C}^{\mathrm{Na}}{ }_{\Pi}$. Барлық өзендердің сулары әлсіз немесе орташа сілтілік ортаны көрсетеді. Өзен суларындағы басты иондардың мөлшері ШРК аспайды $/ 5 /$.

Зерттелетін территориядағы су нысандарының біразы үшін аммонийлі азот көбірек 0,070-0,327 мг/л, ШРК аспайды. Нитратты азот, кремний фтор мөлшері ешқандай су нысанында ШРК аспайды. Табиғи су құрамындағы нитритті азоттың болуы азот қосылыстарымен ластану салдарынан болады. Оның көп мөлшері әсіресе Жайсаң өзенінің суында (6,1 ШРК) байқалды, Жаман Қоба, Қара Қоба, Шар және Марқакөл өзендерінде мүлдем байқалмаған.

Сонымен қатар, еритін фосфаттар концентрациясы зерттелген 20 нысанның 17-де ШРК мөлшерінен аспайды (1,3 ШРК Шорға және Жайсаң көлдері; Аягөз өзені 1,7 ШРК).

Ауыр металдардың ішінде темір және марганец мөлшері анықталды. Барлық су нысандарының химиялық құрамында 1,0-5,1 ШРК темір, әсіресе Нарын өзенінде, марганец концентрациясы алты нысанда ШРК 1,3-5,0 есе, әсіресе Жайсаң өзенінде байқалған.

Судың ластануының кешенді индексін есептеу 2009 жылдың күз мезгілінде Аягөз өзенінің суының $(1,08)$ және Жайсаң $(1,58)$ орташа ластанған, ал қалғандарын таза $(0,30-0,98)$ суларға жатқызуға болатындығын көрсетті.

Нарын өзені мен Жайсаң көлінің суында қосымша басқа да ауыр металдардың: мыстың (50 ШРК) және мырыштың (5 ШРК) - 0,05; қорғасын - 0,02; кадмий 0,002; сынап 0,0002 (20 ШРК) мг/л болатындығы анықталды.

Жер беті суларының сапасына суды жинайтын территориялардың урбанизациясы анықтаушы рөл атқарады. Ластаушы заттарға көшеге тасталған қалдықтар, жол жабындыларының және топырақтың бұзылуы, тазарту жүйелері, өндірістер жатады. Жауын суларымен ластанған осы нысандар су қоймаларына түседі де суларды ластайды. Су көп болған жылдары өзендердің ластануы әсіресе азот және мұнай өнімдерінің мөлшері бойынша Өскемен, Семей және Павл қалаларында артады

Зерттеу мәліметтері сулардың ластануын төмендетуге, сонымен қатар өндіріс қалдықтарының атмосфераға қаншалықты тасталатынын есепке алуға мүмкіндік береді, сонымен қатар осыған жол бермеу жолдарын қарастырудың мүмкіндіктерін ашады.

\section{Әдебиеттер}

1. Кушникова Л.Б. Гидроэкология природных вод бассейна Верхнего Ертиса в районе деятельности промышленных предприятий. - Автореф. дисс. канд. наук, Алматы, 2010.- 17с.

2. Базарбаев С.К., Бурлибаев М.Ж., Кудеков Т.К., Муртазин Е.Ж. Современное состояние загрязнения основных водотоков Казахстана ионами тяжелых металлов. - Алматы: Каганат, 2002. - $256 \mathrm{c}$.

3. Информационный экологический бюллетень Республики Казахстан / Министерство экологии и природных ресурсов // 2001-2008 гг. - Алматы: изд-во «Конжик».

4. Ежегодники качества поверхностных и морских вод и эффективности проведенных водоохранных мероприятий по территории Республики Казахстан (за 1988-1996 гг.) - Алматы, Казгидромет, 1997 г. - 208 с. 
5. Романова С.М., Кушникова Л.Б. и др. Химический состав воды рек и водоемов ВосточноКазахстанской области за многолетний период// Вопросы географии и геоэкологии- Алматы. 2010. - №3 (июльсентябрь).-С.14-18.

\title{
КАЧЕСТВО ВОДЫ РЕК ЕРТИССКОГО ГИДРОЭКОЛОГИЧЕСКОГО РАЙОНА
}

\author{
С.М. Романова, Ж.Д. Достай, Р.Г. Рыскалиева
}

Приведен анализ литературных данных и материалы собственных исследований по оценке качества воды основных рек Ертисского гидроэкологического района.

\section{WATER QUALITY OF RIVERS DISTRICT ERTISSKOGO HYDROECOLOGICAL}

S.M. Romanova, Zh.D Dostay, RG Ryskalyeva

An analysis of published data and materials of their own studies to assess the water quality of major rivers Ertisskogo hydroecological area

\author{
УДК 546.244:[542.91+541.11]
}

\section{СИНТЕЗ И ТЕРМОХИМИЯ НОВЫХ МЕТАЛЛОСМЕШАННЫХ ТЕЛЛУРИТОВ}

\section{К.Т. Рустембеков, А.Т. Дюсекеева, 3.М. Шарипова, Ә. Аманжан}

\section{Карагандинский государственный университет имени Е.А. Букетова, Караганда, Казахстан, e-mail: rustembekov_kt@mail.ru}

\begin{abstract}
Впервые твердофазным способом синтезированы теллуриты некоторых $s$ - $d$-элементов. Методом динамической калориметрии в интервале 298,15 - 673 К исследованы изобарные теплоемкости соединений, на основании которых выведены уравнения температурных зависимостей $C_{p}{ }^{o} \sim f(T) u$ определены

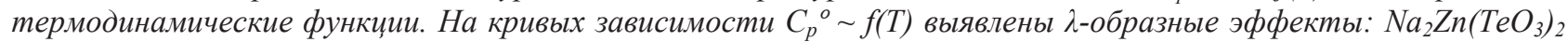
$(348,523 \mathrm{~K}), \mathrm{CaZn}\left(\mathrm{TeO}_{3}\right)_{2}(348,473 \mathrm{~K})$, возможно, относящиеся к фазовому переходу II-рода.
\end{abstract}

Перед современной неорганической химией поставлено немало задач как теоретического, так и прикладного характера. Среди них наиболее важными остаются проблема установления корреляции между составом, строением и свойствами веществ; выявление закономерностей протекания процессов с участием сложных неорганических соединений; использование результатов целенаправленного исследования такого рода соединений для проведения неорганического синтеза; а также разработка новых методов извлечения индивидуальных соединений из многокомпонентного сырья. Все это позволяет не только расширять спектр знаний в отношении исследуемых соединений, но и предоставляет возможность проведения системного анализа, а также служит основанием для осуществления направленного синтеза или селективного извлечения новых неорганических соединений с заданными ценными физико-химическими свойствами.

С этой точки зрения всестороннего и систематического исследования соединений на основе теллура, обладающих такими физико-химическими свойствами как полупроводниковыми, сегнето- и пьезоэлектрическими, вызывают огромный интерес. Кроме того, исследования последних лет, проводимые в этой области химии, показали, что полинеорганические соединения, синтезированные на основе типичных и переходных металлов и неметаллов вместе, с большей долей вероятности проявляют разнообразие в физико-химических свойствах. А полителлуриты, а также двойные теллуриты s-d-элементов, в этом отношении, являются малоизученными соединениями. С учетом вышеизложенного, можно констатировать факт, что систематическое исследование методов синтеза, установление строения и изучение рентгенографических, термодинамических и электрофизических свойств полителлуритов, а также двойных теллуритов s-d-элементов представляют значительный как практический, так и теоретический интерес для неорганического материаловедения и составляют актуальную проблему современной неорганической химии.

В связи с этим нами проводятся систематические исследования по поиску и разработке научных основ направленного синтеза новых оксосоединений теллура с уникальными электрофизическими свойствами /1, 2/. Современная, взаимосогласованная 